\section{Géneros}

Multidisciplinary Journal of Gender Studies

\section{Hipatia Press \\ www.hipatiapress.com}

Instructions for authors, subscriptions and further details:

http://generos.hipatiapress.com

\title{
Limerence Causing Conflict in Relationship between Mother-in- Law and Daughter-in-Law: A Study on Unhappiness in Family Relations and Broken Family
}

Harasankar Adhikari ${ }^{1}$

1) Department of Social Work, Visva Bharati-Santiniketan, West Bengal, India

Date of publication: June $25^{\text {th }}, 2015$

Edition period: June 2015 - October 2015

To cite this article: Adhikari, Harasankar (2015). Limerence Causing Conflict in Relationship between Mother-in-Law and Daughter-in-Law: A Study on Unhappiness in Family Relations and Broken Family. Multidisciplinary Journal of Gender Studies, 4(2), 739-757. doi: $10.4471 /$ generos.2015.56

To link this article: $h t t p: / / d x . d o i . o r g / 10.447 / g e n e r o s .2015 .56$

\section{PLEASE SCROLL DOWN FOR ARTICLE}

The terms and conditions of use are related to the Open Journal System and to Creative Commons Attribution License (CC-BY). 


\section{Limerence Causing Conflict in Relationship between Mother- in-Law and Daughter-in-Law: A Study on Unhappiness in Family Relations and Broken Family}

Harasankar Adhikari

Visva Bharati-Santiniketan

\section{Abstract}

This paper examines the mother-in-law and daughter-in-law relationship and its causes and consequence for future of family. For this study, twenty five each, mothers-in-law and daughters-in-law were interviewed and interacted to know the status of the above relationship. From this study, it revealed that their relationship was suffering from various causes. Among these, limerence (an emotional state of being love) was the prime. The son (her husband) was the limerent object to whom her mother(-in-law) was attached from his birth and she did not like to shift it to her wife(daughter-in-law). This was the main reason of their conflict which was creating psychological and social problems in their family life. This same gender discrimination was the burden of peaceful living. In this global era, it would be overcome through adjustment and sharing of their place of limerence.

Keywords: limerence, mother-in-law and daughter-in-law relationship, same gender discrimination, unhappy family, son as limerent object. 


\section{La Limerencia como Causa de Conflicto en la Relación entre Suegras y Nueras: Un Estudio sobre la Infelicidad en las Relaciones Familiares y las Familias Rotas}

Harasankar Adhikari

Visva Bharati-Santiniketan

\section{Resumen}

Este artículo examina la relación entre suegras y nueras y su impacto en el futuro de la familia. Para este estudio se han entrevistado a veinticinco suegras y veinticinco nueras para conocer el estado de su relación pasada. A partir de este estudio, se reveló que su relación adolecía de diversas causas. Entre ellas, primaba la limerencia (un estado de enamoramiento). El hijo (o marido) fue objeto limerente de la madre, al que estaba unido desde su nacimiento y no quería ceder a su esposa (nuera). Esa fue la principal razón del conflicto, que dio lugar a problemas psicológicos y sociales en la vida familiar.

Palabras clave: limerencia, relación suegras y nueras, discriminación en el mismo género, familia infeliz, hijo como objeto limerante. 



\section{Adhikari-Limerence Causing Conflict in Relationship between Mother-in-Law and Daughter-in-Law}

I n-law relationships are unique one in every society. It is defined as a third party relationship by both a marriage and a blood relationship. Some anthropologists argued that in-law relationships are important to societies, both past and present, because they represent an alliance between two groups of blood relations (Wolfram, 1987). In these cultures, in-law relationships are clearly defined and circumscribed by explicit institutional arrangements and prescribed and proscribed behaviors (Goetting, 1990). From Western ideology, however, we find that the husband-wife marital bond is the central family tie and supersedes claims of the extended family. Despite agreement about the rules of membership, the codes of conduct associated with in-law relationships remain nebulous. The actual interactions and sentiments assigned to these relationships are subject to individuals' definitions (Goetting, 1990). Some patterns are restricted to relationships between parents-in-law and children-in-law. Other in-law relationships, such as that between sisters- or brothers-in-law, appear to be solely based on friendship or idiosyncratic relations (Finch, 1989). The research on in-law relationships has focused on assistance and support patterns. These patterns reflect the distinctive feature of in-law relations, which is that they are generally conducted through and, in a sense, for the sake of a third party (Finch, 1989). Children-in-law primarily receive support from parents-in-law as indirect beneficiaries of parental aid to married children. Hence, the primary patterns of contact and support between children-in-law and their parents-in-law reflect customary patterns of parent-child relationships. In fact, the birth of the first child transforms the mother-in-law and daughter-in-law relationship into one involving significant support patterns. Daughter with preschool children needs and receives usually more help from both mothers and mothers-in-law. Mothers-in-law are more likely to give things, whereas mothers are more likely to do things. Daughters-in-law tends to seek help and advice more frequently from their mothers than from their mothers-in-law and are more likely to express ambivalence about help from their mothers-in-law (Fischer, 1983). Further, the flow of support for in-laws from the child generation to the parent generation is indirect and reflects patterns of gender differences associated with parental care. Parents are more likely to turn to daughters and, thereby, sons-in-law for help than to sons and 
daughters-in-law. However, help to the elderly, which does not usually entail financial support, is more restricted to services and help with household tasks and personal care (Kivett, 1992; Powers, 1992; Schorr, 1980). This type of support is primarily performed by daughters, not sons or sons-in-law. In fact, elderly parents prefer daughters as their caregivers. When daughters are not available geographically or absent in a family, parents turn to sons and daughters-in-law for help during illness and other causes (Kivett, 1992; Powers, 1992). There is also some evidence, however, that caring for mothers-in-law is perceived as more stressful and requiring more tasks than caring for a mother (Steinmetz, 1988).

So, the dynamics of the relationships between mother-in-law and daughter-in-law are very much significant in everyday conversation, popular cultural, jokes and television shows. But there have not been widely studies on this subject. A few studies (Denmark \& Ahmed, 1989) explored that children were found to perceive greater interpersonal distance and have more negative attitudes towards mother-in-law than mothers. Stack (1974) focused in his study that the support pattern between in-laws and children was based on service and financial aid. There has been less empirical evaluation of relationships between in-laws and children because rarely available data and variation in in-laws relationship in different contexts. However, in-laws relationship is determined by happiness, stability and other social, cultural and economic functions in the family. In India, in most cases, in-laws relationship are either causing violence or harassment or torture against each other or it breaks the family relation through emergence of another household. The assumptions are made in general that it involves with revenge, insecurity, dominance and other psycho-social and cultural aspects among in-laws.

To study the dynamics of in-laws relationships, we might not focus our discussion on traditional aspects rather it would be highlighted two main aspects- (i) importance of psycho-social magnitude of mothering and motherhood and its expectation from off-spring and (ii) another one is limerence (being in love) - an emotional state yielded from mother and child attachment.

At first we would look that women are born naturally mothers with capacities, dispositions, and desire to nurture child(ren). Ideologically, construction of intensive mothering is inculcated three aspects - (i) mother 


\section{Adhikari-Limerence Causing Conflict in Relationship between Mother-in-Law and Daughter-in-Law}

as central care-giver, (ii) mother devotes "lavishing copious amounts of time, energy and materials resources on child", and (iii) "mother regards mothering as more important than paid work'. So, mothering/motherhood involves with child-centred, expert guide, emotionally absorbing, labourintensive and financially expensive. The mother and child relationship is highly emotional and physically dependent (O'Reilly, 2004). From mother's womb, attachment (Ainsworth \& Bowlby, 1991) and an ontological security bind mother and child together (Giddens, 1991). The mothering and motherhood as cultural practice turn towards emotional and social security to mother and her family. So, from pregnancy, mother is only care-giver to her child whose happiness indicates mother's happiness.

This mother-child dependent relationship forms an affectional bonding with each other. It is deeply rooted between two. But the child's bonding with his/her mother gradually reduces due to his/her changing emotional state, needs and demands matching with up-bringing process and emergent of other social network of relationships.

The emotional state is a feeling as state of limerence (being in love), a condition of cognitive obsession as well as mental activity (Tannov, 1999). This bonding state between two individuals is a desire for more than sex. It represents mother-child reciprocation through physical union creating the ecstatic and blissful condition for "the greatest happiness". Thus after birth a child, mother's limerence may begin and nurtures by appropriate condition and child becomes her object of a new limerent passion rather than her husband or any one. It transforms from one to another. The child is the limerent object to his/her mother. Affection and fondness have no "objective". They simply exist as feelings in which one disposes towards action to which receipt might or might not respond. In contrast, limerence demands return. Mother and son relationship balances of hopes and uncertainty. She dreams for her son's future that renews her family after getting marriage which strengthens their family tie. Simultaneously, she feels to be rejected by her son because her limerent object would be captured by another intimate one who is her daughter in law and she is his sexual partner.

From time immemorial, the relationship between mother-in-law and daughter-in-law has been unique. The authority, integrity, order-city, 
mutual understanding and compromises are key determinants of this relationship (Denmark \& Ahmed, 1989). The son (her husband) is the focal point of this relationship. The in-laws relationships are generally affectionate, understanding from in-laws, formal and strained relationship which are of lower quality and create distance between parties concerned. Many times, in-laws might be estrangement, leading to angry, outburst and even blocking of communication. Traditionally, financial related to dowry and other expected contributions from daughter's-in-law family leads to emotional estrangement and strained relationships, daughter-in-law usually faces threats and she is fearful about unwanted interference of the motherin-law. On the other part, mother's-in-law shows over possessiveness, and creates tension because she feels that her son's love and attention would be exclusively claimed by an outsider (daughter-in-law). Her reluctance and resistance towards financial and administrative control of the family creates critical situations in their family. Consequently, it yields a threat in the mother's mind so that she reacts in a negative manner and leading to hurt feeling in daughter-in-law (Murickan, 2002). Thus after few months to years, it breaks due to strife between mother in law and daughter-in-law which is the cause of division of family (Rossi \& Rossi, 1990).

In India when a man marries he gets a wife, where as a woman gets a whole family, whose whims and fancies she has to pander to. Through this, the mother-in-law gets as new daughter and the daughter-in-law, a new mother. But this relationship does not become healthy mostly according to the desire of both sides. Both of them finger to each other for their bitterness in their relationship while both of them express like as daughter or mother respectively. The daughter-in-law is possessive that the motherin-law might have about her son (her husband). The mother tends to feel insecure and fears to lose her in born attachment/bonding with her son because her son would no longer need her which was once mandatory from his birth and his wife would fulfill his every need. The emotional commitment gradually pushes her into some psychological disorders to physical suffering. Nevertheless, she tries to feel insult when the young couple goes out leaving her alone at home, and they use to chat with each other and so forth. In such cases, the mother starts demanding attention from her son and she uses to create some scenes for that. On the other hand, the wife in turn starts pestering her husband for separate establishment 


\section{Adhikari-Limerence Causing Conflict in Relationship between Mother-in-Law and Daughter-in-Law}

away from the mother because she suffers from the problem of illogical interference in their conjugal relationship. This is the fact that occurs in everyday family life almost in every family in India society. It causes the truncated family relationship in our society and it fosters violence and marital disturbances which sometimes becomes so irritating that both of them take the help of law and order authority for its resolution. In words, role expectation and role performance are the causes of conflict and the son (her husband) is limerent object is central point of this conflict.

The paper would examine how limerence was central point of this conflict between mother-in-law and daughter-in-law and what would be a remedial strategy to rebuild this relationship towards a healthy state.

\section{Methods}

The research design for this study was simple exploratory study. The threesome relationships of mother-in-law, son (her husband) and daughterin-law were not determined by social, educational, economic and cultural background. The son was the centri-focal parameter who used to balance the relationships and he was the limerent object to both of them. Further, limerence never depends on any socio-religious, educational and economical background of anyone involved with this state. In this study, the mother's demanded her affection towards her son as her birth right and daughter-in-law (his wife) claims as her conjugal right for rest of the life. That's why the researcher ignored consciously the personal background of informants in this study. The mother-in-law and daughter-in-law relationship was generally a negative to all regardless of their any personal background. Almost all of the families used to suffer from the crisis in poor relation representation.

Thus, twenty five mothers-in-law and equal number of daughters-in-law were randomly selected without considering their social, economic and other background from Kolkata, only metro city of eastern India. This urban population had been settled themselves in new emergent urban housing colony. Some of them were not living together with mother-in-law or daughter-in-law. But they were connected with each other daily. They had been in an in-law relationship for between one and ten years. For the 
purpose of this study, they were interviewed separately through unstructured interview schedule. They shared their different experiences of being either mother-in-law or daughter-in-law. The qualitative data included the dynamics of their relationship, its cause and effects in everyday life. How their power and authority, dominance, non-judgmental attitude, adjustment problems and limerence were impacted for happiness and disturbance in their relationships. The interviews were also conducted with ten fathers-in-law and fifteen sons (her husbands) were also shared their opinion regarding their relational representation to their mothers and also to their wives. The interaction and observation were used to collect information. The interviews were recorded and then transcribed.

\section{Result and Discussion}

\section{Dynamics of Mother-in-law and Daughter-in-law's Relationship}

From analysis of transcribed interviews, we find that the many faceted of discord predominated daughters-in-law speech about mothers-in-law. Seventeen of mothers-in-law/daughters-in-law relationship, as described by daughters-in-law was "strained", "uncomfortable", "infuriating". Fifteen mothers-in-law described being in the company of a daughter-in-law as "tensed", uneasy", "uncomfortable". Five mothers-in-law felt a daughter-inlaw was "a precious friend" or "as good as a daughter". Three mothers-inlaw admitted to hating as well as harassment to a daughter-in-law. Out of ten fathers-in-law, seven of them said a daughter-in-law was "nice enough" and their relationship was "all right". Three of them expressed hostility primarily in defense of their wives, who suffered in their mother-inlaw/daughter-in-law relationship.

The interviews with mothers-in-laws mentioned that about $10 \%$ of them considered their daughters-in-law as enemy and $29 \%$ of them considered as only in-law. When the questions asked regarding joint sharing, the mothersin-law replied, $42 \%$ of their daughters-in-law never asked for advice and $55 \%$ of them asked sometimes for advice while they used to take advice from their mothers. Here, it was also recorded the mother and son relationship after the marriage of their sons. Of them, $23 \%$ son's relationships were gotten worse and $51 \%$ of their relationship was in static position. But in case of rest $20 \%$, it was showed better than before their 


\section{Adhikari-Limerence Causing Conflict in Relationship between Mother-in-Law and Daughter-in-Law}

marriage. Gradually, the mothers-in-law faced trouble in relationships with their daughters-in-law traditionally. Of them, $47 \%$ shared that there was no changed, while $20 \%$ of them shared that it was gotten worse day by day.

Another important aspect of relationship was shared by mothers-in-law that daughter-in-law (40\%) used to criticize them to their sons (their husbands) and $15 \%$ of them criticized regarding their style of mothering. They felt angry towards their daughters-in-law because $20 \%$ of them were kept apart from grandchildren. When they were asked about spare of their leisure especially during holidays, $13 \%$ of these mothers-in-law replied that it was just impossible. Thereafter, $10 \%$ of them opined that they did not like daughters-in-law at all and further, $14 \%$ of them told that they liked them sometimes. Twenty percent of these mothers-in-law shared that their daughters-in-law were not suitable/matched with their sons. Last of all, they made some criticisms about their daughters-in-law. Among them, 20\% shared that their daughters-in-law tried to keep their sons away from their mother, according to them (11\%), their daughters-in-law were not good housekeeper, $10 \%$ of them said that they spent too much money. Finally, they shared that majority (58\%) of them would like to stay far away from their sons and daughters-in-law.

\section{Daughters'-in- law Experiences and Opinions towards Their Mothers'- in-law: Their Behaviour and Image in Their Relations}

A large daughters-in-law discourse, centred around the mothers-in-law, was on the mothers'-in-law failure of recognition or validation for aspects of their identity, they themselves valued highly. In this context, they opined that mothers-in-law showed preference for their son's career, and expected the daughters-in-law to sacrifice her career to that of her husband.

According to one thirty two years old daughter-in-law,

I love my mother-in-law, but I can't depend on her support. She'll always be biased towards my husband's career. If she was my mother, I'd fight back. But fighting a mother-in-law over this something I cannot win. She may be feminist, but she is a mother first. She wants her son to be happy. 
A twenty six years old woman (daughter-in-law) shared that her motherin-law (a school teacher),

(...) was generally supportive of women and on the surface, all for equally at home, but when I told her about a new job offer, she did not support it. I was really shocked by her comments. She told that it would not be possible to her because of commuting problem and her absence from household would be a difficulty. Thereafter, I cannot trust her with this stuff.

There was another common view was intrusion - either on the ground that the mother-in-law seemed to "baby" the husband, or on the grounds that the mother-in-law presented herself as weak and needed to be "mothered" by the son.

A daughter-in-law of about 36 years old and a housewife explored,

She (mother-in-law) phones in the morning when we were in bed, and she says how sorry she is to disturb us, but she had to make sure he got back safely from his business trip. She does not see that he is a growing man, she does not believe he can be all right without her.

In our study, one daughter-in-law said, "She expects him to come round late at night even to change a light bulb. She wants him at her beck and call".

The magnitude of mother and son relationships would be strained when a daughter-in-law aged about 40 years and a high school teacher who lived with her husband and only daughter in her parental house discussed her problem relating to her mother-in-law. She shared,

I had taken this decision due to my mother's-in-law attitude towards me. She used to try to make separation between me and my husband. She was very much angry because our marriage was of our choice (love marriage) and from where she did not get any dowry gift which was expected by her. She did not want a marital stability. She counseled her son to dissolve our relationship and for this, she offered rewards to her son. She pressured him to stay only with her. Initially, when I took this decision, my husband tried to convince me that it would not be right thing to live her parents. He 


\section{Adhikari-Limerence Causing Conflict in Relationship between Mother-in-Law and Daughter-in-Law}

told me that after some years, it would be resolved. Anyway, my mother-in-law usually visits us in any occasion. But her behaviour towards her son does not change. She usually creates scene in gathering and this is intolerable.

Daughters-in-law also critically viewed their mother-in-law in the context of her involvement with housework and child care. Majority of the mothers-in-law used to advise their daughters-in-law for housework and child care. Their role was an instructor while they did not come to assist. Practically, it was the basic difference between mother-in-law and mother according to the daughters-in-law. They were non-supportive and nonnegotiable when daughters-in-law did not any wrong and they shared their experiences in this connection. One daughter-in-law in this study shared,

When I was busy to carry out my household duty, my baby was crying. So, I left my house work and took care of my baby. But my mother-in-law did not co-operate. On the other hand, she was shouting for her tea and snacks. But I always expect that she would extend her support and co-operation for a healthy family life.

\section{Sons' Views as Central Figure of Mother-in-law and Daughter-in-law Relationship}

Sons are the central point of building up of this mother-in-law and daughter-in-law relationship. He has respect and is affectionate with his mother. Before his marriage, his mother is his sincere partner of his every joy and sorrow. On the other part, after getting marriage, he gets her new partner for his whole and he renews his family. His wife is not only his sexual partner. She is also his friend and part and parcel of his every prospect. She also is his co-decision maker. But most them shared that they did not interfere in this conflict. They (sons) had no choice and preference. They did not want to face any conspiracy in this connection. They shared that everyone had particularly special role and importance. Keeping the peace and harmony of the family, they should adjust and compromise.

A son of about 35 years old shared another story of his unhappiness with his mother. His mother was widower and his father died when he was a 5 years child. She brings him facing social and economic hardship. He was 
an educated and a public servant with good position. His mother was always with him. After some years of his job, he got married according to her mother's choice. But the problem was started after 3 months of marriage. Lastly, he divorced her with one and half years. He shared his relational aspect that his mother was jealous and she always tried to him within her grip. She did not allow passing a happy conjugal relationship. She brought her daughter-in-law to only take household care:

I was indifferent and I never like to hurt my mother because for her dedication and sacrifice for my establishment in my career, I stood here. But being mother she did not compromise with my future happiness, prosperity and progress in our conjugal relationship.

\section{Mothers(-in-law) Attitude and Behavior in Relations to their Sons and Daughters-in-law: Sons as Limerenent Object of the Mothers}

After birth of her son, a mother is delighted supremely with "the pleasure that makes life worth living" and the experience of motherhood takes the other things more dying. Her will power makes her delightful to revolt anything in this planet. Thus a child becomes limerent object (LO) to his mother for whom she was distracted from her happiness and hence, child was central point of attention and concern. Her son as LO is being usually crystallized by mental events in which she feels attractive towards her son. It makes her blind of loving to him. Affectional bonding with her son makes him as stimuli in her daily life and she builds up her immediate association with him. Her thoughts encircles for welfare of him. This is a "moment of consummation" which yields a climax of commitment between two. Any change of this reciprocation might bring a risk of premature selfdisclosure. The interplay is delicate, with the reactions of each person inextricably bound to the behaviours of the other (Tannov, 1999). It gives birth of fear of rejection, hope for resolution of sons' relations with their daughters-in-law and they are very much jealous considering the change in body language of their sons after their marriage and it is due to their daughters-in-law as new limerent object to their sons. Thus, a middle aged mother (in-law) confronted:

Today my son is grown and I remember when he was a baby boomer. He was an adorable child. Every one commented. I was 


\section{Adhikari-Limerence Causing Conflict in Relationship between Mother-in-Law and Daughter-in-Law}

offered a service with good package. But I rejected because I did not leave him alone. I dreamt to raise him without any difficulty. I felt for my decision of joining service would push him a loneness state. But now he has changed him due to his wife. His wife misguides him. She did not want my son comes to me and to be touched with me. She cultivates a wall of separation between us. It creates a lot of tension in my mind because without my son how I would pass my rest life. It would be better if I die shortly.

\section{Relationships between Two (Mother-in-law and Daughter-in-law) in a Competitive Nature}

The root of this relationship problem lies in women's competitive nature. There are two women in love with same man. This is the conflict of limerent object. Mother's affectional bonding; and wife's love and sex relations are parallel in these relationships. However, if a mother-in-law understands that she will always have a special place in her son's heart, then she can enjoy this younger woman as a friend with new things to teach her and who can in turn learn from her wisdom and life experience which requires friendship with time, space and boundaries.

But many daughters-in-law viewed that whole concept of mother-in-law as a betrayal to their own mothers-perceiving a mother-in-law to be a stepmother trying to replace their primary relationship. Thinking of their personal insecurity was another cause of conflict.

One mother-in-law aged about 55 years expressed her limerence to her son which was distracted by her daughter-in-law. In her words,

My son was very much dependent and caring to me. He used to regularly share his every state of joys and sorrows. We used to take food altogether and used to go to shopping and usually we attended relatives in any occasion. He was very much affectionate to her younger sister. But after some years of his marriage, he forgets all and he uses to deny. His wife is now all. Even, he takes food separately with his wife and he shows his anger when I ask him for anything. He uses to consult everything with his wife. I do not believe that he would change like this. I feel sorrow when I reminiscence his acts from childhood to before his marriage. Now 
my son and daughter-in-law said that I have been suffering from psychological problem.

Thereafter, the interview was recorded separately from her son and daughter-in-law. Her son expressed, "My mother does not like to leave me to do anything according to our own selves. She is dominant in nature from my childhood and a psychological patient. She behaves rudely with my wife". Daughter-in-law said, "Her interference in our lives is disgusting. She does not know how to be respected. She thinks that her son is still a baby".

\section{Effects of Limerence in Threesome Relationships of Mother-in-law - Son (Her Husbad) - Daughter-in-law}

'Women are not born, but made'. The men's and women's bahaviour is ingrained, reflecting innate and essential differences between the sexes. The anatomical and physiological characterizes signifies maleness and femaleness (Beauvoir, 2011). Gender constructs socially masculinity and feminity which are defined by social, cultural and psychological attributes in a particular society at a particular time. Thus gendering and gender practices in our society underpin a particular gender system of male dominance and discrimination. This system exists in relation to social and economic aspects as social whole (totality). These are intertwined through two material processes - production and reproduction. Thus production and reproduction relations are the cause of gender biasedness and also gender discrimination (Engels, 1948) because the right to property and emergence of marriage institution transform the women as men's property. The Female lives are being trapped within the realm of reproduction with social scale and domestic duties. They are trained to perform all above duties through their different stages- daughter, wife, mother and so forth (Wadley, 1988). In their life stages, motherhood as cultural practice (Rich, 1996) is revered as a moral, religion and even artistic deal. It brings family acceptance and emotional well-being. Motherhood is personal fulfillment of womanhood as well as biological achievement of a lifelong promise. From this stage of life, limerence shifts from husband to her child(ren). They use to dream for a new future goal in their life. In fact, the gender preference in Indian society adds important value to male child because a male child is parental future security. So, the expectation and dependency towards male is high in particular, while female child as their (mothers) replica as guest in their 


\section{Adhikari-Limerence Causing Conflict in Relationship between Mother-in-Law and Daughter-in-Law}

parental family. It cultivates a same gender competition among women which we find in mother-in-law and daughter-in-law relationships. Both of them are dependent of male as son (her husband). Their lives are surrounded by males in different roles.

Mother and son are limerent with each other. Mother wants to keep her limerent object (son) intact. She does not accept of shifting of it or she does not allow whole hearted the entrance of other in this state. But her son shifts her limerent object after his marriage to his wife (daughter-in-law) who is also his sexual partner. This shifting is the cause of conflict and same gender discrimination in mother-in-law and daughter-in-law relationships. This alteration of limerent object brings changes in mother's attitude and behavior in relation to her emotional state with feeling of insecurity, fear of rejection and so forth. It is obvious according to the social and psychological characteristics of limerence. This same gender competitiveness causes maladjustment and non-negotiable relationships between mother-in-law and daughter-in-law. That's why, daughter-in-law shows negligence or avoidance towards her mother-in-law. This poor relational representation affected variously in our study. This study revealed that about $56 \%$ of them lived separately while they were in the same city within a distance of hardly within $5-7 \mathrm{~km}$. Twenty percent lived together, but mothers-in-law and daughter-in-law did not interact with each other. About $12 \%$ of them (daughters-in-law) filed for divorce because their husbands (their son) were supporting their mothers(-in-law) and they had to force their wife to obey the interference as well as dominance of their mothers(-in-law).

The shifting of limerent object affected the mental health of mothers(-inlaw) adversely because majority of them had been suffering from high blood pressure, blood sugar, gastric problems and cardiovascular problems, etc. Interestingly, as it might be considered as superstition, the mothers(-inlaw) had been praying to their transcend 'God' to get back to her son from the grip of their daughters-in-law. Their sons' attachment to there is considered as grip to them. But on the other part, daughters-in-law (about $48 \%$ ) were in mental disturbance. But they replied that behavior and attitude of their mothers-in-law was just vague and it was their inferiority 
complex. They thought that mothers-in-law should come out from this stage.

\section{Conclusion}

Limerence has crucial role in human relations and it is the source of living together in family as well as in particular society. The human beings regardless of their gender are tied up only limerence (emotional state of being in love). Their everyday acts of living is a reflection of limerence because everybody is in their functions to society his/her limerent object. It might be considered as source of inspiration attached to their limerent objects. This emotional state does not include sexual act between the partners. Particularly, it might be a final stage of sexual act sometimes (between lovers/husband-wife/others).

Thus, mother-son/child relationships bind them together by limerence from his birth. Mother's happiness is determined by her son's happiness. She nurtures him for his up-bringing with care and attention. She dreams his future and future relationships with him for her safety and security in elderly life.

Mother always binds his son in a nuptial relationship by marriage of her son. She gets her new friend and primarily she (mother-in-law) enjoys that her son would be secured at the time of her absence. But the close proximity of relationships between son and daughter-in-law breaks her emotional state and she fears of rejection by her limerent object (son). So, she tries to control her son's with arrogant attitude and domination and other acts towards her daughter-in-law. She does do some acts by which she would be capable to break their (son and daughter-in-law) closeness and affection. She forgets to remember that her son and daughter-in-law is limerent object with each other and they are also sexual partner. This is central point of disturbance between two. It is being shed with limerence only. That's why, there is a competition in their relationship and both of them try to show off their importance and essentiality to their targeted male.

In this study, it had been proved that the limerence is the only prime factor of unhappy and unhealthy mother-in-law and daughter-in-law relationships. The same gender discrimination due to this limerence encircles generation after generation. The women shift their stages of status from daughter to mother to wife to mother-in-law (grandmother). But they 


\section{Adhikari-Limerence Causing Conflict in Relationship between Mother-in-Law and Daughter-in-Law}

keep intact their limerence with their sons. The study revealed that mothersin-law were the main responsible factor of their relational disturbance. They used to finger towards daughters-in-law. Thus, their mental illness/psychological problems lead them to a critical elderly life. They used to suffer from various lifestyle diseases. They used to live alone and their limerence had broken their family life in a truncated relationship. So, everybody should understand this state of limerence. They should learn to adjust with their shifting of limerent object as a psychological need which fulfills social needs through happy relationship. Otherwise, it would never change its dynamics. Once, woman was a victim of this state, when she was wife. But when she becomes mother-in-law, she practices it to victim other of her gender. Further, the above state of limerence may explain with the help of Treisman's Theory of Vomiting (Treisman, 1977). It explores that vomiting and malaise are part of an early defense and warning system inappropriate in the case of motion, but lifesaving in of toxin ingestion. So, it is that motion of sickness is an accident by-product of the organism's response to certain head and eye moments that occur in the case of food poisoning, but unfortunately, also in the case of certain types of theorizing. It conjectures about the "survival value". This relationship is the same with postulate of this theory of vomiting.

Equality and justice towards women would be accelerated through women's co-operation and support because in our patriarchy male domination would not erase forever. Further, feminism teaches to come out from male domination, but anti feminism directs woman without man is just impossible. In this case, everybody should concentrate their faith, hope, love and insight for promoting a healthy family life and harmony of their family. Their sensation, thinking, feeling, and intuition are impacted differently which gives birth of a quarrelsome behavior.

Finally, there is need of counseling to the mothers-in-law and daughters-in-law for promotion of a healthy family for their own survival.

\section{References}

Ainsworth, M. D. S., \& Bowlby, J. (1999). An ethological approach to personality development. American Psychologist, 46(4), 333-341. Beauvoir, S. (2011). The Second Sex. London: Vintage. 
Denmark, F. L. \& Ahmed, R. A. (1989). Attitudes Towards Mother-in-Law and Stepmother: A Cross Cultural Study. Psychological Report, 65, 1194

Engels, F. (1948). The origin of the Family, Private Property and the State. Mascow: Progress Publishers.

Finch, J. (1989). Family Obligations and Social Change. Cambridge, UK: Polity Press.

Fischer, L. R. (1983). Mothers and Mothers-in-Law. Journal of Marriage and the Family, 45(1), 187-192. doi: 10.2307/351307

Giddens, A. (1991). Modernity and Self Identity. UK: Polity Press Goetting, A. (1990). Patterns of Support Among In-Laws in the United States: A Review of Research. Journal of Family Issues, 11(1), 6790. doi: 10.1177/019251390011001005

Kivett, V. R. (1985). Consanguinity and Kin Level: Their Relative Importance to the Helping Network of Older Adults. Journal of Gerontology, 40(2), 228-234. doi: 10.1093/geronj/40.2.228 Murickan, S. J. (2002). Marriage and Human Fulfillment, New Delhi:

Classical Publishing Company.

O’ Reilly, A. (2004). From Motherhood to Mothering. USA :State University of New York Press.

Powers, E. A., \& Kivett, V. R. (1992). Kin Expectations and Kin Support Among Rural Older Adults. Rural Sociology, 57,194-215.

Rich, A. (1996). Of Women Born: Motherhood as Experience and Institution. USA: W.W Norton \& Company

Rossi, A. \& Rossi, P. (1990). Of Human Bonding. New York: Walter de Gruyter.

Schorr, A. L. (1980). Thy Father and Thy Mother: A Second Look at Filial Responsibility and Family. Washington, DC: U.S. Government Printing Office.

Stack, C. B. (1974). All our kin. New York: Harper \& Row.

Steinmetz, S. K. (1988). Duty Bound: Elder Abuse and Family

Care. Newbury Park, CA: Sage Publications

Tannov, D. (1999). Love and Limerence: The Experience of Being in Love. USA: Scarborough House.

Treisman, M. (1977). Motion Sickness : An Evolutionary Hypothesis. Science, 197(4302), 493-495. doi: 10.1126/science.301659 
757 Adhikari-Limerence Causing Conflict in Relationship between Mother-in-Law and Daughter-in-Law

Wadley, S. (1988). Women and the Hindu Tradition. In R. Ghadially (Ed.), Women in Indian Society: A reader (pp. 23-43). New Delhi, India: Sage Publication.

Wolfram, S. (1987). In-Laws and Out-Laws: Kinship and Marriage in England. London: Croom Helm.

\section{Harasankar Adhikari}

Contact address: Department of Social Work, Visva BharatiSantiniketan, West Bengal, India

E-mail address: jaoya123@yahoo.co.in 